\title{
ASPEK YURIDIS ALIH FUNGSI TROTOAR JALAN SEBAGAI LOKASI PEDAGANG KAKI LIMA
}

\author{
GENTUR CAHYO SETIONO \\ Fakultas Hukum Universitas Kadiri \\ Jl. Selomangleng No. 1 Kediri \\ Email : gentur@unik-kediri.ac.id
}

\begin{abstract}
Abstrak
Tujuan dari penelitian ini adalah untuk mengetahui efektifitas Peraturan daerah Nomor 7 Tahun 2014 Tentang Penataan dan Pemberdayaan Pedagang Kaki Lima serta Peraturan Walikota Kediri No. 37 Tahun 2015 Tentang Petunjuk Pelaksanaan Peraturan Daerah Kota Kediri Nomor 7 Tahun 2014 Tentang Penataan dan Pemberdayaan Pedagang Kaki Lima dalam mengatasi permasalahan keberadaan Pedagang Kaki Lima yang menggunakan fasilitas umum di Kediri. Penelitian ini menggunakan metode yuridis sosiologis yaitu "metode penelitian yang berusaha mengidentifikasi penerapan hukum (substansi hukum) sebagai suatu norma atau kaidah produk pemerintah dan peranan lembaga atau institusi hukum dalam penegakan hukum di masyarakat". Dalam pelaksanaan penataan pedagang kaki lima langkah yang dilakukan oleh pemerintah daerah kediri adalah melakukan penataan waktu berjualan yang diperbolehkan bagi pedagang kaki lima penataan waktu tersebut disesuaikan dengan tingkat kepadatan ruas jalan yang ada dikota kediri.
\end{abstract}

\section{Latar Belakang Masalah}

Dalam rangka menjalankan roda kehidupan berbangsa dan bernegara pemerintah Indonesia memiliki tujuan untuk menciptakan kesejahteraan sosial bagi seluruh rakyatnya. Tujuan tersebut diwujudkan dengan menerbitkan serangkaian kebijakan dalam menjalankan pemerintahan yaitu dengan membuat suatu kebijakan yang mempermudah bagi pelaksanaan rencana program-program pemerintah.

Untuk mencapai tujuan tersebut pemerintah Indonasia baik pemerintah pusat maupun pemerintah daerah membuat kebijakan-kebijakan publik dalam bentuk peraturan perundang-undangan, pelaksanaan kebijakan tersebut memiliki tujuan untuk memberikan kesejahteraan bagi masyarakat Indonesia. Salah satu

Gentur Cahyo Setiyono, Aspek Yuridis ALih Fungsi Trotoar Jalan Sebagai Lokasi Pedagang Kaki Lima 
tugas yang menjadi perhatian pemerintah sesuai dengan amanat UUD 1945 adalah kebijakan-kebijakan yang terkait dengan penyediaan kesempatan kerja bagi masyarakat luas baik melalui sektor formal maupun informal.

Pekerjaan sebagai Pedagang Kaki Lima (PKL) merupakan salah satu bentuk kesempatan kerja disektor informal. Keberadaan pedagang kaki lima merupakan bentuk kegiatan ekonomi rakyat yang banyak berkembang didaerahdaerah perkotan di wilayah Indonesia. Keterbatasan kesempatan kerja di sektor formal yang dipengaruhi oleh berbagai faktor dimana diantaranya adalah keterbatasan lapangan kerja dan besarnya pencari kerja, keterbatsan modal dan rendahnya tingkat pendidikan menjadi faktor pesatnya perkembangan pedagang kaki lima.

Menurut Kamus Bahasa Indonesia Kontemporer (1991) "pedagang kaki lima adalah pedagang yang menjual barang dagangannya di pinggir jalan atau di dalam usahanya menggunakan sarana yang mudah dibongkar pasang atau dipindahkan serta menggunakan bagian jalan atau trotoar, tempat-tempat yang tidak diperuntukan bagi tempat untuk berusahaatau tempat lain yang bukan miliknya".

Keberadaan pedagang kaki lima sebagai salah satu penopang kebutuhan ekonomi bagi masyarakat khususnya bagi kalangan masyarakat menengah kebawah, namun dilain pihak adanya pedagang kaki lima tersebut juga menjadikan sebuah permasalahan tersendiri di daerah-daerah perkotaan. Pedagang kaki lima dalam menjalankan kegiatannya sering menggunakan ruang publik yang fungsi sebenarnya bukan merupakan tempat untuk melakukan aktifitas perdagangan.

Gentur Cahyo Setiyono, Aspek Yuridis ALih Fungsi Trotoar Jalan Sebagai Lokasi Pedagang Kaki Lima 
Keberadaan pedagang kaki lima yang melakukan aktifitas berjualan di ruang-ruang publik selain menggangu ketertiban dan keindahan juga mengganggu aktifitas pengguna jalan dimana pejalan kaki yang seharusnya memiliki sarana trotoar sebagai tempat beraktifitas tidak mendapat tempat sebagaimana mestinya, menyempitnya ruas jalan karena adanya aktifitas pedagang kaki lima yang pada ahkirnya juga akan menyebabkan terganggunya keselamatan pengguna jalan baik pejalan kaki maupun kendaraan dan juga menyebabkan kemacetan.

Permasalahan-permasalah terkait keberadaan pedagang kaki lima di kota kediri, merupakan permasalah yang perlu dijadikan perhatian bagi pemerintah sebagai organ yang memiliki fungsi melakukan kontrol sosial. Tindakan penanganan pedagang kakii lima berdasarkan atas suatu kebijakan publik, yaitu baik berupa Undang-undang, peraturan pemerintah dan peraturan daerah serta payung hukum lainnya yang mengatur tentang pedagang kaki lima dan fungsi ruas jalan.

Terkait fungsi ruas jalan pemerintah telah mengeluarkan Undang-undang No. 22 Tahun 2009 Tentang Lalu Lintas Jalan Raya (UU LLAJ) yang berlaku untuk membina dan menyelenggarakan lalu lintas dan angkutan jalan yang aman, selamat dan tertib. Terkait penggunaan trotoar menurut pasal 131 ayat (1) UU LLAJ ketersediaan fasilitas trotoar merupakan hak pejalan kaki, ini artinya bahwa trotoar diperuntukan untuk kepentingan pejalan kaki, bukan untuk kepentingan pribadi dan kepentingan-kepentingan lain.

Selaras dengan ketentuan tersebut dalam pasal 34 ayat (4) Peraturan Pemerintah Nomor 34 Tahun 2006 tentang jalan menyatakan bahwa “trotoar 
sebagai mana yang dimasksud dalam ayat (3) hanya diperuntukan bagi lalu lintas pejalan kaki".

Merujuk pada peraturan penanganan pedagang kaki lima pemerintah kota Kediri telah mengeluarkan peraturan-peraturan terkait penanganan pedagang kaki lima diantaranya adalah Peraturan daerah Nomor 7 Tahun 2014 Tentang Penataan dan Pemberdayaan Pedagang Kaki Lima serta Peraturan Walikota Kediri No. 37 Tahun 2015 Tentang Petunjuk Pelaksanaan Peraturan Daerah Kota Kediri Nomor 7 Tahun 2014 Tentang Penataan dan Pemberdayaan Pedagang Kaki Lima.

Idealnya setelah ada peraturan diperlukan bentuk tindakan nyata agar apa yang diinginkan oleh hukum dapat terwujud. Hukum tidak dapat bekerja tanpa penegak hukum dan peran masyarakat luas yang ikut mendukung penegakan hukum. Ketaatan masyarakat atas hukum dapat berasal dari paksaan, dalam bukunya Soedjono Dirdjosisworo menyebutkan bahwa:

a. Masyarakat hanya mungkin berlangsung oleh hukum;

b. Baik dalam hukum maupun dalam kesewenang-wenangan terdapat pemaksaan. ${ }^{1}$

Hukum seharusnya mampu hadir sebagai alat control social yang bersifat mendidik, mengajak dan memaksa masyarakat yang diatur agar mematuhi kaidah atau norma yang berlaku, sehingga hak-hak dan kewajiban anggota masyarakat dapat terjaga..

${ }^{1}$ Soedjono Dirdjisisworo, Pengantar Ilmu Hukum, RajaGrafindo, Jakarta, 2005, hal. 93.

Gentur Cahyo Setiyono, Aspek Yuridis ALih Fungsi Trotoar Jalan Sebagai Lokasi Pedagang Kaki Lima 


\section{Perumusan Masalah}

Berdasar uraian tersebut dapat dirumuskan permasalahan, yakni apakah menurut hukum dapat dibenarkan pemanfaatan trotoar jalan sebagai lokasi pedagang kaki lima!

\section{Manfaat Penelitian}

Adapun manfaat dari penelitian ini secara praktis adalah sebagai bahan masukan bagi pemerintah, khususnya pemerintah kota Kediri dan instansi yang terkait dalam rangka penanganan PKL yang memanfaatkan trotoar jalan untuk berjualan. Sedangkan secara akademis penelitian ini diharapkan dapat dijadikan salah satu acuan bagi penelitian selanjutnya, khususnya yang berkaitan dengan pedagang kaki lima dan alih fungsi trotoar jalan.

\section{Tinjauan Teori}

Dalam proses kehdupan berbangsa dan bernegara masyarakat tidak dapat dipisahkan dari hukum, konstitusi merupakan sebuah kontrak social yang terbentuk antara yang diperintah yaitu rakyat dengan yang memerintah yaitu pemerintah. Sebuah Negara merupakan hasil dari perbuatan manusia, sehingga kepentingan individulah yang harus diperhatikan, perlindungan hak dengan pembatasan dimaksutkan untuk menjamin pengakuan serta penghormatan terhadap hak dan kebebasan masyarakat untuk memenuhi rasa adil sesuai dengan nilai-nilai moral, agama, dan ketertiban umum.

Karakteristik hukum adalah sifatnya yang memaksa dimana dipertegas dengan penerapan sanksi bagi pelanggarannya, agar peraturan-peraturan yang telah ditetapkan benar-benar dapat ditaati sehingga menjadi kaidah hukum, maka peraturan tersebut harus dilengkapi dengan unsur memaksa. Dengan demikian 
hukum memiliki sifat mengatur dan memaksa setiap orang agar menaati tata tertib yang telah ditetapkan.

Hukum dapat bekerja dengan baik dipengaruhi oleh beberapa faktor yang saling menunjang dan terintegrasi satu ama lain, dalam proses penegakan hukum banyak Faktor yang mempengaruhi bekerjanya hukum, Robert B. Siedman mengemukakan teorinya mengenai Faktor-faktor bekerjanya hukum, yaitu:

1. Peraturan perundang-undangan;

2. Aparat pelaksana/penegak hukum;

3. Masyarakat/kesadaran dan kepatuhan hukum. ${ }^{2}$

Bekerjanya hukum menurut Siedman ini adalah menyatukan tiga Faktor, yaitu Faktor pembuat undang-undang yang dalam hal ini adalah legislatif, faktor pelaksana undang-undang dalam hal ini adalah eksekutif dan Faktor social lain yang juga memegang peran, yaitu masyarakat dalam hal ini menyangkut kesadaran hukum masyarakat.

Hukum sebagai suatu sistem dalam penerapannya tidak hanya mengacu pada peraturan saja, namun juga mencakup hal-hal lain, Lawrence M. Friedman mengemukakan bahwa efektif dan berhasil atau tidaknya penegakan hukum tergantung pada tiga unsur sistem hukum yaitu, struktur hukum (struktur of law), substansi hukum (substance of the law) dan budaya hukum (legal culture) $)^{3}$ :

1. Substansi hukum (substance of law), yaitu aturan atauran atau isi dari suatu peraturan;

2. Struktur hukum (structure of law), yaitu pihak-pihak yang terkait dalam penegakan suatu peraturan/aparat penegak hukum;

\footnotetext{
${ }^{2}$ Abdurrahman, Tebaran Pikiran Tentang Studi Hukum dan Masyarakat, MSP, Jakarta, 1987, hal. 58.

${ }^{3}$ Achmad Ali,Menguak Teori Hukum Dan Teori Peradilan, Kencana, Jakarta, 2003, hal. 34.

Gentur Cahyo Setiyono, Aspek Yuridis ALih Fungsi Trotoar Jalan Sebagai Lokasi Pedagang Kaki Lima
} 
3. Budaya Hukum (Legal Culture), yaitu perilaku-perilaku masyarakat dalam memandang kaidah-kaidah atau norma hukum untuk ditaati.

Ketiga Faktor dalam system hukum tersebut sangat tergantung satu sama lain dalam proses penegakan hukum dalam masyarakat, karena apabila substansi hukumnya sudah baik harus didukung pula oleh struktur hukum yang baik juga, serta culture hukum yang melahirkan kesadaran hukum.

Dalam pembentukan subtansi suatu peraturan harus memperhatikan aspek kepentingan penguasa sebagai organ yang memiliki kewenangan mengatur dan aspek kepentingan masyarakat sebagai organ yang diatur melalui aturan tersebut. Struktur dalam hukum baik pemerintah maupun penegak hukum tentu dalam menjalankan tugasnya-tugasnya harus sesuai dengan aturan dan menerapkan apa yang telah diatur dalam peraturan yang telah ditetapkan tersebut, sehingga apa yang telah dijadikan tujuan dari pembentukan peraturan tersebut dapat diwujudkan, serta budaya masing-masing imdividu dalam masyarakat dapat menerima dan menerapkan aturan tersebut.

Efektifitas dalam tindakan atau realita hukum dapat diketahui apabila seorang menyatakan bahwa suatu kaidah hukum berhasil atau gagal mencapai tujuannya, maka hal itu biasanya diketahui dari apakah norma hukum berhasil mengatur tingkah laku tertentu masyarakat sehingga sesuai dengan tujuan pembentukan peraturan atau tidak.

Efektifitas hukum merupakan teori dimana orang benar-benar berbuat sesuai dengan norma/kaidah-kaidah hukum sebagai mana kewajiban mereka, bahwa norma tersebut harus benar-benar diterapkan dan dipatuhi. Untuk 
mengetahui apakah hukum tersebut benar-benar diterapkan dan dipatuhi oleh masyarakat maka harus dipenuhi beberapa Faktor: ${ }^{4}$

1. Faktor hukumnya sendiri;

2. Faktor penegak hukum;

3. Faktor sarana atau fasilitas yang mendukung penegakan hukum;

4. Faktor masyarakat;

5. Faktor kebudayaan.

Kelima Faktor tersebut saling berkaitan erat oleh karena merupakan inti dari penegakan hukum tersebut yang merupakan tolok ukur atas efektifitas hukum, jadii apabila semua unsur tersebut telah terpenuhi maka tujuan hukum dalam masyarakat dapat dirasakan, yaitu kepastian hukum, keadilan, dan kemanfaatan.

\section{Metode Penelitian}

1. Jenis penelitian dan pendekatan masalah

Dalam penelitian hukum ini metode pendekatan masalah yang digunakan adalah yuridis sosiologis yang mana dalam penelitian data doperoleh dari data primer dan data sekunder", yaitu "metode penelitian yang berusaha mengidentifikasi penerapan hukum (substansi hukum) sebagai suatu norma atau kaidah produk pemerintah dan peranan lembaga atau institusi hukum dalam penegakan hukum di masyarakat".

\footnotetext{
${ }^{4}$ Soerjono Soekanto, Faktor-Faktor Yang Mempengaruhi Penegakan Hukum, RajaGrafindo, Jakarta,2013, hal. 8.
}

${ }^{5}$ Mukti Fajar ND, Dualisme Penelitian Hukum, Pustaka Pelajar, Yogyakarta, 2009, hal. 48

Gentur Cahyo Setiyono, Aspek Yuridis ALih Fungsi Trotoar Jalan Sebagai Lokasi Pedagang Kaki Lima 
Sedangkan jenis penelitian yang digunakan adalah deskriptif yaitu jenis penelitian yang sifatnya mendiskripsikan atau menjelaskan peraturan-peraturan yang ada dan berlaku sebagai hukum positif.

\section{Jenis Data}

Jenis data yang digunakan dalam penelitian ini adalah data primer dan sekunder.

a. Data Primer.

Data primer merupakan keterangan atau fakta yang diperoleh secara langsung melalui penelitian lapangan, baik dengan wawancara atau studi lapang secara langsung dalam hal ini adalah pihak-piha yang terkait dengan obyek penelitian.

b. Data Skunder

Data skunder merupakan data yang diperoleh melalui studi kepustakaan yaitu berupa penelusuran peraturan perundang-undangan, buku literatur, dokumen, majalah, internet serta hasil penelitian terdahulu yang memilikii hubungannya dengan obyek yang diteliti.

3. Teknik Pengumpulan data

a. Untuk mengumpulkan data primer, dilakukan dengan cara wawancara yaitu melakukan Tanya jawab secara langsung dengan responden yaitu dalam hal ini dinas yang terkait dengan penertiban pedagang kaki lima yaitu satuan polisi pamong praja, dan pedagang kaki lima yang menempati trotoar jalan sebagai lokasi berdagang.

Gentur Cahyo Setiyono, Aspek Yuridis Alih Fungsi Trotoar Jalan Sebagai Lokasi Pedagang Kaki Lima 
b. Untuk mengumpulkan data sekunder, dilakukan dengan penerapan peraturan perundang-undangan yang terkait, hasil penelitian, hasil karya ilmiah, kamus dan buku literature yang ada kaitannya denga pokok permasalahan yang dibahas.

\section{Analisis Data}

Dalam menganalisis data yang dikumpulkan, digunakan analisis deskriptif kualitatif yaitu "suatu analisis yang sifatnya menjelaskan atau menggambarkan mengenai peraturan-peraturan yang berlaku yang terkait dengan obyek yang diangkat dalam penelitian, dalam hal ini adalah peraturan-peraturan yang terkait dengan pengaturan pedagang kaki lima dan fungsi trotoar jalan serta didukung dengan data yang diperoleh dari hasil observasi, quisioner dan wawancara".

\section{Pembahasan}

\section{Gambaran Umum Kota Kediri}

Luas wilayah kota Kediri adalah 63,40km2 dan merupakan kota sedang di Provinsi Jawa Timur. Terletak didaerah yang dilalui sungai brantas dan si bawah lembah gunung wilis dengan ketinggian 2552 meter. Kota kediri berpenduduk 312.000 jiwa terletak antara $07^{\circ} 45^{\circ}-07^{\circ} 55^{\prime}$ Lintang Selatan dan $111^{\circ} 05^{\circ}-112^{\circ} 3^{\circ}$ Bujur Timur, dari aspek topografis kota kediri terletak pada ketinggianrata-rata 67 meter di atas permukaan laut, dengan tingkat kemiringan 0-40\%. Struktur kota terbelah menjadi 2bagian oleh sungai brantas, yaitu sebelah timur dan barat sungai. Wilayah dataran rendah terletak di daerah timur sungai meliputi wilayah kecamatan kota dengan luas wilayah 14,900 km2 terdiri dari 17 kelurahan dan kecamatan pesantren dengan luas wilayah 23,903 km2 terdiri dari 15 kelurahan, sedangkan dataran tinggi terletak pada bagian barat sungai yaitu kecamatan Mojoroto dengan luas wilayah 24,601 km2 terdiri dari 14 kelurahan.

Secara administratif kota kediri terdiri dari 3 kecamatan dan 46 kelurahan, dengan batas wilayah sebagai berikut :

Gentur Cahyo Setiyono, Aspek Yuridis ALih Fungsi Trotoar Jalan Sebagai Lokasi Pedagang Kaki Lima 
1. Sebelah utara : kecamatan gampengrejo dan kecamatan grogol, kabupaten kediri.

2. Sebelah selatan : kecamatan kandat dan kecamatan ngadiluwih, kabupaten kediri

3. Sebelah timur : kecamatan ngasem, kecamatan wates, dan kecamatan gurah, kabupaten kediri

4. Sebelah barat : kecamatan banyakan dan kecamatan semen kabupaten kediri.

Perkembangan kota kediri didukung oleh peningkatan kualitas dari berbagai sektor, yaitu pendidikan, pariwisata, perdagangan, industri dan birokrasi. Industri rokok gudang garam merupakan penopang perekonomian bagi sebagian besar rakyat kota kediri, sekitar 16.000 masyarakat menggantungkan perekonomian merekan terhadap perusahaan rokok gudang garam.

\section{Gambaran Umum Pedagang Kaki Lima di Kota Kediri}

Tidak dapat dipungkiri keberadaan pedagang kaki lima merupakan salah satu bentuk kegiatan perekonomian rakyat yang berkembang didaerahdaerah perkotaan di indonesia, keberadaan pedagang kaki lima merupakan merupakan fenomena kegiatan perekonomian rakyat yang tidak bisa dipisahkan dari keberadaan wilayah perkotaan. Di kota kediri keberadaan pedagang kaki lima sendiri juga menjadi salah satu kegiatan usaha yang penopang perekonomian masyarakat, keberadaan PKL di kota Kediri sendiri banyak tersebar di berbagai tempat baik di daerah Barat sungai dan daerah timur sungai.

Tabel

Data Pedagang Kaki Lima

\begin{tabular}{|c|l|c|}
\hline No & \multicolumn{1}{|c|}{ Daerah } & Jumlah \\
\hline 1 & Jl. Airlangga & 16 \\
\hline 2 & Depan Terminal Baru & 13 \\
\hline 3 & Jagung Suprapto & 5 \\
\hline 4 & Jl. Veteran Timur & 24 \\
\hline 5 & Jl. Veteran Barat & 29 \\
\hline 6 & Pasar bandar (utara) & 16 \\
\hline
\end{tabular}

Gentur Cahyo Setiyono, Aspek Yuridis ALih Fungsi Trotoar Jalan Sebagai Lokasi Pedagang Kaki Lima 


\begin{tabular}{|c|l|c|}
\hline 7 & Jl. Penanggungan & 33 \\
\hline 8 & Jl. Patimura & 15 \\
\hline 9 & Jl. Hayam Wuruk & 26 \\
\hline 10 & Alon-Alon Kota Kediri & 107 \\
\hline 11 & Jl. Brawijaya & 20 \\
\hline 12 & Jl. Kilisuci & 30 \\
\hline 13 & Mauni & 40 \\
\hline 14 & Ahmad yani & 26 \\
\hline 15 & Tembus lebak tumpang & 48 \\
\hline 16 & Bantaran sungai brantas & 9 \\
\hline 17 & Taman sekartaji Total & 471 \\
\hline & & \\
\hline
\end{tabular}

Data Kantor Satpol PP Kota Kediri.

Berdasar atas data yang diperoleh jumlah PKL yang terdata di Kantor Satpol PP berjumlah 471 PKL, jumlah PKL paling besar terdata berada di kawasan Alon-alon Kota kediri yaitu sejumlah 107 PKL. Menurut Sucipto Komandan Regu Penertipan Satpol PP Kota Kediri, sampai saat ini petugas satpol PP masih terus melakukan pendataan terhadap PKL yang ada di kota kediri, dalam hal ini pihak Satpol PP berkordinasi dengan ketua Aliansi paguyupan PKL kota kediri.

Rekapitulasi hasil kuisioner 25 PKL di daerah Jl. Veteran dan bandar sekitar Rumah sakit Gambiran.

\section{a. Pendidikan}

\begin{tabular}{|l|l|l|l|}
\hline No & Pendidikan & Jumlah & Persentase \\
\hline 1 & SD & 7 & $28 \%$ \\
\hline 2 & SMP & 14 & $56 \%$ \\
\hline 3 & SMA & 4 & $16 \%$ \\
\hline 4 & SARJANA & - & $100 \%$ \\
\hline
\end{tabular}

b. Jenis Barang Dagangan

\begin{tabular}{|l|l|l|l|}
\hline No & Dagangan & Jumlah & \\
\hline 1 & Makanan/Minuman & 21 & \\
\hline 2 & Barang & 4 & \\
\hline 3 & Jasa & - & \\
\hline
\end{tabular}

c. Lama berjualan

\begin{tabular}{|l|l|l|l|}
\hline No & Waktu & Jumlah & \\
\hline
\end{tabular}

Gentur Cahyo Setiyono, Aspek Yuridis Alih Fungsi Trotoar Jalan Sebagai Lokasi Pedagang Kaki Lima 


\begin{tabular}{|l|l|l|l|}
\hline 1 & $<5$ jam & 6 & \\
\hline 2 & $5-10$ jam & 18 & \\
\hline 3 & $>10$ jam & 2 & \\
\hline
\end{tabular}

d. Cara menyimpan sarana dagangan

\begin{tabular}{|l|l|l|l|}
\hline No & Sarana dagangan & Jumlah & \\
\hline 1 & Ditinggal & - & \\
\hline 2 & Dibawa pulang & 12 & \\
\hline 3 & Dititipkan di sekitar lokasi & 13 & \\
\hline
\end{tabular}

e. Alasan berjualan di Trotoar

Dari pertanyaan ini sebagian besar PKL menjawab bahwa alasan mereka adalah karena keterbatasan modal dan mencari lokasi strategis di daerah yang ramai.

f. Keinginan PKL Jika ada penataan oleh pemerintah

\begin{tabular}{|l|l|l|l|}
\hline No & Penataan PKL & Jumlah & \\
\hline 1 & $\begin{array}{l}\text { Dipindah ke lokasi kusus } \\
\text { PKL }\end{array}$ & 2 & \\
\hline 2 & Penataan di lokasi sekarang & 14 & \\
\hline 3 & Lainnya & 9 & \\
\hline
\end{tabular}

g. Pengetahuan tentang larangan berjualan di trotoar

\begin{tabular}{|l|l|l|l|}
\hline No & Pengetahuan Aturan & Jumlah & \\
\hline 1 & Tahu & 25 & \\
\hline 2 & Tidak tahu & - & \\
\hline
\end{tabular}

h. Tarikan/iuran dari pemerintah

\begin{tabular}{|l|l|l|l|}
\hline No & Iuran & Jumlah & \\
\hline 1 & Ada & 25 & \\
\hline 2 & Tidak ada & - & \\
\hline
\end{tabular}

Apabila kita perhatikan dari data yang diperoleh banyak faktor yang menyebabkan tumbuhnya pedagang kaki lima di kota kediri, faktor pendidikan menjadi salah satu faktor terbesar yang menentukan jenis pekerjaan apa yang akan dilakukan oleh seseorang dalam memenuhi kebutuhan hidupnya, pilihan menjadi pedagang kaki lima dikarenakan rendahnya pendidikan dan 
keterampilan yang mereka miliki karena menjadi PKL tidak memerlukan keterampilan/skill kusus yang menunjang.

Faktor lain yang tidak kalah penting adalah permasalahan modal, mereka tidak memiliki kemampuan untuk menyewa tempat untuk berjualan, hal inilah yang pada ahkirnya mendorong PKL memanfaat trotoar untuk tempat dagangan mereka dari pada menyewa tempat untuk berdagang, modal yang kecil serta laba yang didapat daru usaha tidak bisa dipergunakan untuk mengembangkan usaha sehingga keuntungan yang didapat hanya bisa dipergunakan sebagai pemenuhan kebutuhan hidup sehari-hari.

Terkait model penataan yang diinginkan terhadap aktifitasnya sebagian besar dari PKL meginginkan dilakukan model penataan ditempat mereka berjualan saat ini, berdasr hasil wawancara dengan PKL mereka tetap ingin berjualan dilokasi tersebut karena alasan daerah tersebut merupakan tempat yang strategis, ramai pengunjung dan sudah banyak pelangan yang membeli dagangan mereka di daerah tersebut.

\section{Kebijakan Penataan PKL Di Kota Kediri}

Keberadaan Pedagang kaki lima di kota kediri merupakan suatu masalah yang harus segera diselesaikan oleh pemerintah kota kediri. Keberadaan PKL yang tidak tertata dengan baik yang berjualan di ruang-ruang publik serta menggunakan fasilitas trotoar dan bahu jalan akan menimbulkan kesan buruk baik dari segi keindahan kota dan mengganggu aktifitas dan keselamatan pejalan kaki, menyempitnya ruas jalan yang pada ahkirnya juga akan menyebabkan terganggunya keselamatan pengguna jalan baik pejalan kaki maupun kendaraan dan juga menyebabkan kemacetan.

Gentur Cahyo Setiyono, Aspek Yuridis Alih Fungsi Trotoar Jalan Sebagai Lokasi Pedagang Kaki Lima 
Untuk menjaga keselamatan pejalan kaki dalam melakukan aktifitasnya, pejalan kaki wajib berjalan pada bagian jalan dan menyeberang pada tempat yang telah disediakan bagi pejalan kaki, dalam hal ini hak dari pejalan kaki dilindungi oleh Undang-undang Nomor 22 Tahun 2009 tentang Lalu-Lintas dan Angkutan Jalan. Dalam Pasal 131 disebutkan :

1) Pejalan kaki berhak atas ketersediaan fasilitas pendukung yang berupa trotoar, tempat penyeberangan dan fasilitas lain;

2) Pejalan kaki berhak mendapatkan prioritas pada saat menyeberang jalan di tempat penyeberangan.

3) Dalam hal belum tersedia fasilitas sebagaimana termaksut dalam ayat (1) pejalan kaki berhak menyeberang ditempat yang dipilih dengan memperhatikannya keselamatannya.

Dari penjelasan pasal tersebut memberikan pengertian bahwa pejalan kaki memiliki hak atas ketersediaan fasilitas pendukung yang berupa trotoar dan tempat penyeberangan, trotoar merupaka hak bagi pejalan kaki, trotoar merupakan jalur bagi pejalan kaki dipinggir jalan raya yang posisinya lebih tinggi dari jalan raya yang disediakan untuk memberikan hak yang sama bagi pejalan kaki dengan pengguna jalan lainnya dan juga untuk menjamin keselamatan dan kenyamanan pejalan kaki dalam melakukan aktifitasnya.

Penataan dan penertiban pedagang kaki lima penting dilakukan karena mereka dalam melakukan aktifitas perdagangannya selalu memanfaatkan fasilitas umum seperti lahan-lahan kosong, emperan toko, trotoar jalan dan bahu jalan, hal ini tentunya akan mengganggu fungsi sebenarnya dari fasilitasfasilitas tersebut. Kondisi trotoar dan bahu jalan yang dipergunakan sebagai 
tempat berdagang pedagang kaki lima akan mengganggu hak pejalan kaki yang sebenarnya memiliki hak atas adanya fungsi trotoar jalan.

Kebijakan pemerintah daerah kota kediri dalam penataan Pedagang Kaki Lima dalam manjalanlan aktifitas perdagangannya sangat diperlukan, dalam hal ini penataan pedagang kaki lima di kota kediri mengacu pada Perda Nomor 7 Tahun 2014 Tentang Penataan Pedagang Kaki Lima. Menurut pasal 1 butir 4 Perda Nomor 7 Tahun 2014 : "Pedagang Kaki Lima yang selanjutnya disebut PKL adalah pelaku usaha yang melakukan usaha perdagangan dengan menggunakan sarana usaha bergerak maupun tidak bergerak, menggunakan prasarana kota, fasilitas sosial, fasilitas umum, lahan dan bangunan milik pemerintah dan/atau swasta yang bersifat sementara/tidak menetap".

Penataan pedagang kaki lima dalam menjalankan aktifitas perdagangannya merupakan hal penting yang harus dilakukan oleh pemerintah kota kediri, hal ini dimaksudkan agar keberadaan PKL tidak merugikan kepentingan fungsi-fungsi sarana dan prasarana lain seperti fungsi trotoar dan bahu jalan sehingga merugikan bagi pejalan kaki. Banyak faktor yang saling terkait dengan keberadaan pedagang kaki lima dan fungsi trotoar sebagai lokasi PKL berdagang disatu sisi PKL merupakan salah satu sektor pekerjaan Informal yang menopang perekonomian masyarakat dan disisi lain penggunaan trotoar sebagai lokasi berdagang melanggar fungsi sesungguhnya dari trotoar yang merupakan hak bagi pejalan kaki.

Kebijakan pemerintah daerah kota kediri dalam penataan Pedagang Kaki Lima dal am manjalanlan aktifitas perdagangannya sangat diperlukan, dalam hal ini langkah pemerintah kota kediri dalam melakukan penataan 
terhadap pedagang kaki lima dengan menerbitkan Perda Nomor 7 Tahun 2014 Tentang Penataan Pedagang Kaki Lima dan Peraturan Walikota Kediri Nomor 37 Tahun 2015 Tentang Petunjuk Pelaksanaan Peraturan Pemerintah Daerah Nomor 7 Tahun 2014 tentang Penataan Dan Pemberdayaan Pedagang Kaki Lima.

Perda Nomor 7 Tahun 2014 ditetapkan oleh pemerintah kota kediri untuk melakukan penataan dan pemberdayaan Pedagang Kaki Lima, dengan adanya perda tersebut diharapkan akan mampu menyelesaikan permasalahanpermasalahan yang ada terkait dengan keberadaan pedagang kaki lima yang melakukan aktifitasnya di bahu jalan dan trotoar. dalam aturan pasal 1 Perwali No 37 Tahun 2015 ditegaskan bahwa lokasi PKL merupakan tempat usaha bersifat sementara yang terjadwal dan PKL hanya diperbolehkan berjualan pada jadwal waktu yang telah ditentukan. Tempat usaha PKL menurut aturan ini haruslah tempat usaha yang dapat bergerak (dapat dipindahkan) dan harus ditata sehingga tidak menimbulkan gangguan bagi arus lalu lintas.

Berdasarkan hasil dari penelitian penulis kebijakan yang diambil oleh Pemerintah Kota Kediri dalam penataaan dan penertiban pedagang kaki lima adalah dengan melakukan pendataan PKL, Pendaftaran PKL, Penetapan lokasi PKL dan Pengawasan PKL.

1. Pendataan PKL

Pemerintah Kota Kediri melakukan pendataan PKL yang ada untuk mendapatkan dat yang akurat sehingga pelaksanaan penataan PKL dapat berjalan

Gentur Cahyo Setiyono, Aspek Yuridis Alih Fungsi Trotoar Jalan Sebagai Lokasi Pedagang Kaki Lima 
dengan baik. Dengan adanya pendataan ini maka akan diketahui informasi yang dibutuhkan dalam proses penataan PKL di kota kediri. Langkah -langkah pendataan ini dilakukan agar pemerintah kota kediri mendapatkan jumlah pedagang kaki lima yang ada sehingga dapat mempermudah pemerintah dalam proses penataan pedagang kaki lima.

\section{Pendaftaran PKL}

Dalam kebijakan yang diatur oleh pemerintah kota kediri, pihak pemerintah kota mewajibkan bagi para PKL untuk melakukan pendaftaran aktifitas usahanya, proses pendaftaran kegiatan usaha PKL tersebut diajukan ke dinas Perindustrian, Perdagangan, pertambangan dan Energi sesuai dengan mekanisme dan persyaratan yang telah ditentukan dalam Perwali Nomor 37 Tahun 2015. Bagi PKL yang sudah terdata dan memiliki TDU (tanda daftar usaha) dapat melakukan usahanya sesuai dengan zona waktu dan tempat sementara yang sudah ditetapkan oleh pemerintah kota kediri. Proses pendataan dan pendaftaran terhadap kegiatan usaha PKL akan memberikan kemudahan secara administratif bagi pemerintah kota kediri dalam melakukan penataan PKL selain itu kebijakan tersebut juga akan memberi kepastian hukum bagi PKL dalam menjalankan aktifitas usahannya.

\section{Penatapan Lokasi PKL}

Dalam melaksanakan penetapan lokasi usaha bagi pedagang kaki lima dalam rangka melakukan proses penataan, kebijakan yang diambil oleh pemerintah kota kediri adalah dengan mengambil kebijakan tentang pengaturan zona waktu dan tempat yang boleh dijadikan tempat usaha bagi pedagang kaki

Gentur Cahyo Setiyono, Aspek Yuridis Alih Fungsi Trotoar Jalan Sebagai Lokasi Pedagang Kaki Lima 
lima, dengan adanya sistem penzonaan ini akan mempermudah bagi pemerintah

kota kediri untuk melakukan penataan bagi pedagang kaki lima yang ada.

DAFTAR LOKASI DAN JADWAL PKL YANG BERSIFAT SMENTARA

\begin{tabular}{|c|l|c|}
\hline NO & \multicolumn{1}{|c|}{ LOKASI } & WAKTU \\
\hline 1 & $\begin{array}{l}\text { Jl. BANDAR NGALIM (sebelah kiri dan kanan } \\
\text { jalan) }\end{array}$ & $17.00-24.00$ \\
\hline 2 & Jl. DR. SAHARDJO (sebelah kiri dan kanan jalan) & $17.00-24.00$ \\
\hline 3 & $\begin{array}{l}\text { Jl. GATOT SUBROTO (sebelah kiri dan kanan } \\
\text { jalan) }\end{array}$ & $17.00-24.00$ \\
\hline 4 & Jl. JAKGUNG SUPRAPTO (sebelah kiri dan kanan jalan) & $17.00-24.00$ \\
\hline 5 & Jl. KH. AHMAD DAHLAN (sebelah kiri dan kanan jalan) & $17.00-24.00$ \\
\hline 6 & Jl. KH. WACHID HASYIM (barat jalan) & $17.00-24.00$ \\
\hline 7 & Jl. KH.AGUS SALIM (sebelah kiri dan kanan jalan) & $17.00-24.00$ \\
\hline 8 & Jl. SEMERU (sebelah kiri dan kanan jalan) & $17.00-24.00$ \\
\hline 9 & Jl. SUPRIYADI (sebelah kiri dan kanan jalan) & $17.00-24.00$ \\
\hline 10 & Jl. BOTOLENGKET UTARA (sebelah kiri dan kanan jalan) & $10.00-24.00$ \\
\hline 11 & Jl. BUNGA (sebelah kiri dan kanan jalan) & $10.00-24.00$ \\
\hline 12 & Jl. DERMO MRICAN (sebelah kiri dan kanan jalan) & $10.00-24.00$ \\
\hline 13 & Jl. KAWI (sebelah kiri dan kanan jalan) & $10.00-24.00$ \\
\hline 14 & Jl. KH ABDUL KARIM (sebelah kiri dan kanan jalan) & $10.00-24.00$ \\
\hline 15 & Jl. KH. HASYIM ASHARI (sebelah kiri dan kanan jalan) & $10.00-24.00$ \\
\hline 16 & Jl. MASTRIP (sebelah kiri dan kanan jalan) & $10.00-24.00$ \\
\hline 17 & Jl. MERBABU (sebelah kiri dan kanan jalan & $10.00-24.00$ \\
\hline 18 & Jl. NGAMPEL RAYA (sebelah kiri dan kanan jalan) & $10.00-24.00$ \\
\hline
\end{tabular}

\begin{tabular}{|c|l|c|}
\hline NO & \multicolumn{1}{|c|}{ LOKASI } & \multicolumn{1}{|c|}{ WAKTU } \\
\hline 19 & Jl. PENANGGUNGAN (sebelah kiri dan kanan jalan) & $17.00-24.00$ \\
\hline 20 & Jl. RAUNG (sebelah kiri dan kanan jalan) & $17.00-24.00$ \\
\hline 21 & Jl. SELOMAGLENG (sebelah kiri dan kanan jalan) & $10.00-24.00$ \\
\hline 22 & Jl. VETERAN (sebelah kiri dan kanan jalan) & $17.00-24.00$ \\
\hline 23 & Jl. BRAWIJAYA (sebelah kiri jalan) & $17.00-24.00$ \\
\hline 24 & Jl. WACHID HASYIM II (sebelah kiri dan kanan jalan & $10.00-24.00$ \\
\hline 25 & Jl. WIRANTO (sebelah sebelah kiri dan kanan jalan) & $10.00-24.00$ \\
\hline 26 & Jl. DHOHO (sebelah kiri jalan) & $21.00-24.00$ \\
\hline 27 & Jl. ERLANGGA (sebelah kiri jalan & $17.00-24.00$ \\
\hline 28 & Jl. HAYAM WURUK (sebelah kiri jalan) & $17.00-24.00$ \\
\hline 29 & Jl. JEND. A. YANI (sebelah kiri dan kanan jalan) & $17.00-24.00$ \\
\hline 30 & Jl. PAHLAWAN KUSUMA BANGSA (sebelah kiri ) & $17.00-24.00$ \\
\hline 31 & Jl. PATIMURA (sebelah kiri jalan) & $17.00-24.00$ \\
\hline 32 & J1. ADI SUCIPTO (sebelah timur jalan dan barat jalan) & $10.00-24.00$ \\
\hline 33 & Jl. BALOWERTI I & $08.00-24.00$ \\
\hline 34 & J1. BALOWERTI II & $08.00-24.00$ \\
\hline 35 & J1. BANJARAN I & $08.00-24.00$ \\
\hline 36 & Jl. BANJARAN II & $08.00-24.00$ \\
\hline 37 & Jl. CUT NYAK DIEN & $08.00-24.00$ \\
\hline 38 & Jl. HALIM PERDANA KUSUMA & $10.00-24.00$ \\
\hline
\end{tabular}

Gentur Cahyo Setiyono, Aspek Yuridis Alih Fungsi Trotoar Jalan Sebagai Lokasi Pedagang Kaki Lima 


\begin{tabular}{|c|l|l|}
\hline 39 & J1. IR SUTAMI (sebelah utara dan selatan jalan) & $10.00-24.00$ \\
\hline 40 & J1.JOYOBOYO (sebelah timur dan barat jalan) & $17.00-24.00$ \\
\hline 41 & J1. KHAIRIL ANWAR & $08.00-24.00$ \\
\hline 42 & J1. KILI SUCI (sebelah timur dan barat jalan) & $17.00-24.00$ \\
\hline 43 & Jl. KKO.USMAN & $10.00-24.00$ \\
\hline 44 & $\begin{array}{l}\text { Jl.KOMPOL DURYAT (sebelah timur dan barat } \\
\text { jalan) }\end{array}$ & $17.00-24.00$ \\
\hline 45 & Jl. KYAI MOJO & $08.00-24.00$ \\
\hline
\end{tabular}

\begin{tabular}{|c|l|c|}
\hline NO & \multicolumn{1}{|c|}{ LOKASI } & WAKTU \\
\hline 46 & Jl. MATARAM & $08.00-24.00$ \\
\hline 47 & Jl. MEDANG KAMULAN & $08.00-24.00$ \\
\hline 48 & Jl. MONGINSIDI & $17.00-24.00$ \\
\hline 49 & Jl. PANGLIMA POLIM (sebelah timur dan barat jalan) & $08.00-24.00$ \\
\hline 50 & Jl. SAM RATULANGI & $17.00-24.00$ \\
\hline 51 & Jl. SELOWARIH & $08.00-24.00$ \\
\hline 52 & Jl. SEMAMPIR I & $08.00-24.00$ \\
\hline 53 & Jl. SEMAMPIR II & $08.00-24.00$ \\
\hline 54 & Jl. SEMAMPIR V & $08.00-24.00$ \\
\hline 55 & Jl. SEMAMPIR VI & $08.00-24.00$ \\
\hline 56 & Jl. SERSAN HARUN & $08.00-24.00$ \\
\hline 57 & Jl. SLAMET RIADI & $08.00-24.00$ \\
\hline 58 & Jl. SMU 6 & $08.00-24.00$ \\
\hline 59 & Jl. SULTAN AGUNG (sebelah timur dan barat) & $17.00-24.00$ \\
\hline 60 & Jl. SUNAN AMPEL & $17.00-24.00$ \\
\hline 61 & Jl. SUNAN AMPEL III & $17.00-24.00$ \\
\hline 62 & Jl. TRUNOJOYO (sebelah timur dan barat) & $17.00-24.00$ \\
\hline 63 & JL. BRIGJEN POL IMAM BAHCRI & $17.00-24.00$ \\
\hline 64 & Jl. HOS COKROAMINOTO (sebelah timur dan barat jalan) & $17.00-24.00$ \\
\hline 65 & Jl. KAPTEN TENDEAN (sebelah timur dan barat) & $17.00-24.00$ \\
\hline 66 & Jl. AKASIA & $08.00-24.00$ \\
\hline 67 & Jl. BETET BAWANG & $08.00-24.00$ \\
\hline 68 & Jl. BETET PAGU & $08.00-24.00$ \\
\hline 69 & Jl. CENDANA & $08.00-24.00$ \\
\hline 70 & DESA BLABAK & $08.00-24.00$ \\
\hline 71 & Jl. DURIAN & $08.00-24.00$ \\
\hline & & \\
\hline
\end{tabular}

Dari hasil data diperoleh kebijakan penanganan terhadap PKL yang memanfaatkan trotoar sebagai lokasi usaha, Pemerintah kota kediri tidak melakukan relokasi terhadap keberadaan PKL yang melakukan kegiatan usahanya memanfaatkan keberadaan trotoar, tetapi mengatur zona waktu yang diperbolehkan bagi pedagang kaki lima melakukan kegiatan usahanya. Pemerintah kota kediri saat ini belum memiliki lokasi untuk lahan relokasi PKL, sehingga kebijakan penataan PKL mengacu pada Peraturan Walikota Kediri nomor 37 Tahun 2015 dilakukan dengan pengaturan zona waktu, menurut Sucipto 
Komandan Regu Penertipan Satpol PP Kota Kediri ada 5 zona waktu yang digunakan yang dapat digunakan PKL untuk melakukan aktifitas perdagangannya yakni zona pukul 17.00-05.00, zona pukul 08.00-12.00, zona pukul 08.00-17-00, zona pagi sampai jam 22.00 dan zona steril.

Lebih lanjut menurut Sucipto Poin penting dalam penertiban PKL adalah menertibkan arus lalu lintas di kota kediri, arus lalu lintas sudah mulai padat sehingga perlu ada pengaturan yang lebih tertib. Penataan PKL yang mengacu pada pengaturan zona waktu berjualan ini mempertimbangkan pada kepadatan arus lalu lintas di setiap jalan di Kota Kediri, sehingga kebijakan waktu disetiap titik jalan akan berbeda pula tidak bisa dipukul rata sama, akan dilakukan pemetaan daerah-daerah berdasar tingkat kepadatan lalu-lintas untuk mengatur zona waktu seperti di Jl. Imam Bonjol akan berbeda dengan J1. Hayam Wuruk dimana di Jl. Imam Bonjol arus lalu lintas tidak seramai di Jl. Hayam Wuruk maka pengaturan waktu untuk berdagang PKL pasti akan berbeda.

Dalam kebijakan yang diambil berdasar perwali tersebut pihak pemerintah kota kediri hanya akan melakukan penataan pada PKL tanpa melakukan pelarangan bagi PKL untuk berjualan penetapan zona waktu ini merupakan upaya pemerintah kota kediri untuk memecahkan permasalahan PKL dan hak dari masyarakat pengguna fasilitas jalan maupun trotoar. Guna menegakan aturan ini bagi PKL yang tidak mematuhi peraturan yang telah ditetapkan sesuai dengan pasal 40 Peraturan Daerah Kota Kediri Nomor 7 tahun 2014 tentang Penataan dan Pemberdayaan Pedagang Kaki Lima selain dekenakan sanksi administrasi dapat pula dipidana dengan pidana kurungan paling lama 6 bulan atau pidana denda paling banyak 50 juta rupiah. Dengan pemberian sanksi tersebut bertujuan agar PKL dapat mematuhi peraturan yang telah ditetapkan oleh pemerintah kota kediri.

4. Pengawasan PKL

Pasaca pendataan, pendaftar dan penetapan zona waktu dan lokasi yang diperbolehkan bagi PKL untuk melakukan aktifitas perdagangannya, peran petugas Satuan Polisi Pamong Praja Kota Kediri melakukan pengawasan terhadap peraturan yang telah ditetapkan oleh pemerintah yaitu pengawasan terhadap PKL yang melakukan kegiatan usahanya. Dalam rangka penegakan perwali, pihak satpol PP melakukan sweeping dan penertiban bagi PKL yang berjualan tidak 
menaati zona waktu berjualan, menurut Sucipto Komandan Regu Penertipan Satpol PP Kota Kediri petugas satpol PP akan melakukan sweeping secara berkelanjutan di beberapa ruas jalan yang menjadi tempat para PKL menjual dagangannya.

Bagi para PKL yang masih melakukan aktifitas di luar jam yang telah ditetapkan akan diberikan penindakan oleh Satpol PP kota kediri, tindakan yang diambil petugas Satpol PP Kota Kediri bersifat persuasif dengan memberikan peringatan dan pengarahan kepada para PKL agar menaati peraturan yang ada dan berjualan sesuai dengan zona waktu yang telah ditentukan, untuk gerobak atau rombong yang ditinggal pemiliknya di pinggir jalan dibawa petugas ke Mako Satpol PP. Selaku petugas pihak atpol PP akan terus melakukan pembinaan, pengarahan dan sosialisasi kepada PKL agar mereka mematuhi peraturan yang ada karena sebenarnya kebijakan yang diambil pemerintah kota kediri sudah menguntungkan PKL karena pemerintah tidak melarang berjualan namun mengatur waktu-waktu yang diperbolehkan bagi PKL untuk berjualan.

Berdasar hasil penelitian pola kebijakan yang diambil oleh pemerintah kota kediri terkait keberadaan PKL adalah usaha melakukan penataan dan penertiban pedagang kaki lima, adanya perda dan perwali tentang penataan PKL di kota kediri bukan bertujuan untuk menghilangkan dan mematikan usaha pedagang kaki lima melainkan bertujuan agar pedagang kaki lima tetap bisa dipertahankan namun dengan meminimalkan dampak negatif sehingga keberadaan PKL ini tidak banyak menimbulkan masalah dan pejalan kakipun merasa nyaman dan tidak terganggu menggunakan fasilitas trotoar dalam melakukan aktifitasnya. Keseimbangan penataan ruang perlu dijaga agar segala kepentingan masyarakat di kota kediri dapat terpenuhi.

Menilai kebijakan yang diambil oleh pemerintah kota kediri pendekatan hukum yang dilakukan lebih pada pendekatan humanis sosiologis, pendekatan kemanusiaan merupakan faktor dominan yang diterapkan dalam penanganan penataan PKL di kota kediri. Ada banyak kepentingan yang terkait dalam permasalahan penataan PKL, sedapat mungkin pemerintah Kota Kediri akan memberikan solusi yang terbaik bagi kepentingan-kepentingan tersebut sehingga tidak ada pihak-pihak yang merasa diuntungkan atau dirugikan akibat kebijakan 
yang diambil oleh pemerintah kota kediri. Berdasar hasil wawancara dengan anggota Satpol PP permasalahan PKL bukan hanya sekedar penataan dan penertiban saja namun juga terkait masalah perekonomian kususnya bagi masyarakat tingkat menengah kebawah di kota kediri. Kami petugas selain melakukan penertiban juga sedapat mungkin akan menampung keluhan dari PKL yang nantinya akan dapat digunakan sebagai bahan masukan untuk memberikan solusi terbaik terkait masalah penataan PKL di kota kediri. Dalam menegakkan Peraturan yang ada pihak Satpol PP mengambil langkah persuasif yaitu dengan melakukan peringatan dan pengarahan pada PKL agar mematuhi peraturan yang ada.

\section{PENUTUP}

\section{Kesimpulan}

1. Faktor yang menorong pedagang kaki lima menggunakan fasilotas trotoar sebagai lokasi berjualan selain rendahnya tingkat pendidikan, terutama adalah karena keterbatasan modal sehingga mereka tidak mampu menyewa tempat sebagai tempat melaksanakan aktifitas usahanya.

2. Upaya pemerintah kota kediri dalam melakukan penataan pedagang kaki lima yang memanfaatkan ruang publik terutama trotoar yang merupakan fasilitas untuk pejalan kaki dalam melakukan aktifitasnya adalah dengan menetapkan Perda Nomor 7 Tahun 2014 dan Perwali Nomor 37 Tahun 2015 tentang penataan dan pembinaan pedagang kaki lima. Kebijakan yang diambil pemerintah kota kediri dalam penataan pedagang kaki lima adalah tidak melarang PKL berjualan namun mengatur zona waktu dan tempat berjualan bagi PKL, zona waktu di setiap ruas jalan berbeda ditetapkan berdasarkan tingkat kepadatan pengguna jalan. Penegakan hukum yang dilakukan oleh Satpol PP kediri terhadap PKL yang masih melanggar zona waktu yang telah ditetapkan masih bersifat persuasif yaitu dengan memberikan peringatan dan pengarah pada para PKL agar mematuhi peraturan yang ada.

\section{Saran}

Gentur Cahyo Setiyono, Aspek Yuridis Alih Fungsi Trotoar Jalan Sebagai Lokasi Pedagang Kaki Lima 
Bagi pemerintah kota kediri sebaiknya segera memberikan solusi yang lebih baik dalam penataan pedagang kaki lima, perlu segera mengambil alternatif kebijakan untuk mensinergikan kepentingan PKL dan Pejalan kaki sebagai penguna jalan yaitu dengan cara memberikan lokasi tempat berdagang yang strategis bagi para pedagang kaki lima sehingga mereka mudah memasarkan barang dagangannya, sehingga dapat tercipta format penyelesaian kebijakan yang win-win solution kedepan trotoar akan dapat dikembalikan pada fungsinya yaitu sebagai fasilitas bagi pejalan kaki dan kesejahteraan Pedagang Kaki Lima pun dapat diwujudkan. Langkah yang dapat diambil oleh pemerintah kota kediri misalnya :

- Memanfaatkan lahan-lahan kosong yang ada untuk digunakan berjualan PKL.

- Menyediakan beberapa lokasi untuk pedagang kaki lima dengan bentuk cluster-cluster sesuai klasifikasi jenis usaha PKL.

\section{DAFTAR PUSTAKA}

Abdurrahman, Tebaran Pikiran Tentang Studi Hukum dan Masyarakat, MSP, Jakarta, 1987.

Mukti Fajar ND, Dualisme Penelitian Hukum, Pustaka Pelajar, Jogjakarta, 2009

Soerjono Soekanto, Faktor-Faktor Yang Mempengaruhi Penegakan Hukum, RajaGrafindo, Jakarta,2013

Soedjono Dirdjisisworo, Pengantar Ilmu Hukum, RajaGrafindo, Jakarta, 2005

Gentur Cahyo Setiyono, Aspek Yuridis Alih Fungsi Trotoar Jalan Sebagai Lokasi Pedagang Kaki Lima 
Achmad Ali,Menguak Teori Hukum Dan Teori Peradilan, Kencana, Jakarta, 2003.

Perda Kota Kediri Nomor 7 Tahun 2014 Tentang Penataan Dan Pemberdayaan Pedagang Kaki Lima.

Peraturan Wali Kota Kediri Nomor 37 Tahun 2015 Tentang Petunjuk Pelaksanaan Peraturan Daerah Kota Kediri Nomor 7 Tahun 2014.

Undang-undang Nomor 22 Tahun 2009 tentang Lalu-Lintas dan Angkutan Jalan 